\title{
Ticked off, but scared off? Riots and the fate of nonviolent campaigns ${ }^{1}$
}

Luke Abbs (Business and Local Government Data Research Centre \& Department of Government, University of Essex)

Kristian Skrede Gleditsch (Department of Government, University of Essex \& Peace Institute Oslo - PRIO)

\section{Accepted at Mobilization: An International Quarterly}

Existing research on the relationship between nonviolent and violent dissent has focused on primary tactics and explicit shifts in organized strategies. This disregards less-organized forms of violence such as riots during otherwise nonviolent and peaceful mobilization. Even though such disorganized violence is common during mobilization, we know little about how it influences the onset and fate of major nonviolent campaigns. Activists often argue that nonviolent discipline is essential for effective large-scale mobilization, and that riots and disorganized violence will be counterproductive and undermine the emergence or sustenance of mass nonviolent campaigns. However, others emphasize how riots often grow through diffusion, and see spontaneous disorganized violence as events that could have a mobilizing effect on large-scale protest. We detail these competing perspectives on how riots and unorganized violence can influence the onset of large-scale nonviolent campaigns and affect their likely outcomes. We then evaluate empirically the contending claims by examining how riots affect the initial emergence of nonviolent dissident campaigns and the likelihood that campaigns will terminate. We find that riots scale with protest size, and thus may appear to have short-term mobilizing effects on protest. However, once we take into account the common trending, we find that nonviolent mobilization are less likely to emerge after riots, and ongoing campaigns are more likely to collapse under higher rates of rioting.

\footnotetext{
${ }^{1}$ Acknowledgements. We are grateful for comments, suggestions, and helpful discussions with Isabel Bramsen, Tobias Böhmelt, Patrick James, and Gabriel Leon. A previous version of this manuscript was presented at the 2017 annual meeting of the Network of European Peace Scientists in Antwerp, Belgium 26-28 June. Please direct all correspondence to Kristian Skrede Gleditsch, Department of Government, Wivenhoe Park, Colchester CO4 3SQ, UK, ksg@essex.ac.uk.
} 


\section{Incidental violence and nonviolent protest}

Many of the largest and most impactful challenges to autocratic rulers around the world have relied on nonviolent dissident tactics (Chenoweth and Stephan, 2011: 5-12). Sharp (2005: 4960) notes 198 methods of nonviolent resistance within three broad categories: persuasion (i.e. peaceful protests and demonstrations), non-cooperation (i.e. peaceful strikes and boycotts), and intervention (i.e. peaceful sit-ins and the overloading of state institutions). Organized nonviolent resistance and the nonviolent tactics deployed are conceptually distinct from organized violence such as guerrilla warfare or terrorist campaigns. Still, many nonviolent campaigns have been accompanied by varying levels of lower level violence, without planning or coordination, such as riots or individuals fighting with the police. While the existence of rioting is acknowledged in various studies of nonviolent resistance, the lack of research on the impact of disorganized violence leaves us without clear answers as to how the presence and extent of incidental violence may affect the prospects for and fate of otherwise nonviolent campaigns. Does the emergence of rioting help to convey how many are "ticked off", demonstrating the extent of dissatisfaction in ways that helps to promote dissent and sustain nonviolent mobilisation? Or does rioting and crowd violence primarily "scare off" potential sympathizers, thus undermining the likelihood of a campaign and the sustainability of ongoing campaigns by deterring participation and discrediting nonviolent movements?

Activists and organizers often argue that disorganized violence and riots are unhelpful and pose a major challenge for otherwise nonviolent mobilization and the success of campaigns (i.e. Popovic and Miller 2015: 195-214) and may undermine momentum by violently escalating interactions between dissidents and the state (McAdam, 1982). ${ }^{1}$ Yet, existing research also demonstrates that riots often diffuse and spread, which in turn suggests that they could help escalate or mobilize nonviolent dissent (e.g., Aidt et al. 2017). 
Mozambique between 2008-2012, provides an example that illustrates the apparent ambiguous effects of rioting on the prospects of nonviolent mobilization. Mozambique witnessed several episodes of volatile popular unrest between 2008 and 2012. At the beginning of 2008 the government increased domestic consumer prices to offset increasing import prices, and the negative impact on living standards amplified existing grievances and outrage over social inequalities and corruption (BBC 2010). Nonviolent protests emerged quickly in the capital Maputo and its satellite city Matola, and text messages were used to call for a general strike against the price increases. However, the nonviolent protests swiftly descended into rioting, where protesters threw stones and set vehicles on fire, eventually unleashing government repression. Although the protests initially enjoyed a great deal of support and had started to spread to other cities, by February 2008 rioting had effectively shut down Maputo and undermined the momentum for nonviolent elements of the dissent. When protests and riots emerged again in February 2010 and November 2012, the police were prepared and quicker to suppress mobilization (de Brito et al., 2014). Thus, even if riot acts may have helped drawn attention to the protest, they also appear to have undermined the ability to mobilize larger numbers.

In contrast, the Otpor! (Resistance!) movement in Serbia (formally still Federal Republic of Yugoslavia) that toppled Milosević also faced challenges from situations where violence could emerge, but were remarkably successful in overcoming these. Otpor! emerged in October 1998 to challenge a new law restricting freedom of expression in universities, but soon launched a major nonviolent campaign aiming to overthrow the Milosević regime itself. Otpor! were met by threats of sanction and heavy-handed repression by the policy and army, and there were many opportunities for violent responses to emerge. Yet, Optor! proactively strived to avoiding violent responses which they saw as counterproductive, and they were remarkably successful in these efforts. Otpor tried to make repression backfire by using images 
of beaten protesters to channel outrage into participation in the organized nonviolent movement, and created "rapid response teams" to provide legal defence to arrested protesters (Kurtz 2010: 5; Sharp 2005: 315-340). At one stage where hardline football hooligans wanted to join the protests, Otpor! successfully managed to persuade them to stay away, on the grounds that their lack of control and risk of fights with the police could only encourage more repressive responses. ${ }^{2}$ There were only a few large occurrences of disorganized violence, including some clashes with police and an arson event in the parliament building in 2000 (Kurtz 2010: 5; Pinckney 2006: 49-50). Thus, in sharp contrast to Mozambique, the Otpor! Campaign managed to generally contain the risk of disorganized violence and sustain mobilization momentum until Milosevic was compelled to resign in September 2000.

Forms of disorganized violence is a common occurrence alongside many efforts to mobilize nonviolent protest campaigns (see e.g., Belgioioso et al. 2019 on BosniaHerzegovina). For the most widely used dataset on large-scale nonviolent campaigns Nonviolent and Violent Campaign and Outcomes (NAVCO) - we find at least one recorded riot event in the Social Conflict Analysis Database (SCAD), and for 50\% of the campaigns we have more than two riot events. ${ }^{3}$ However, it remains poorly understood how forms of disorganized violence such as rioting, impacts the emergence and sustainability of otherwise nonviolent dissent.

Exploring data across Africa, Figure 1 displays the average number of days with protest events in a specified location recorded in the SCAD data, binned for each month leading up to and after a riot event, during NAVCO/MEC campaigns. This includes both escalatory riots coded as emerging directly from initial nonviolent protests, as well as fringe riots deemed to simply occur in parallel with nonviolent protests. The dashed horizontal lines indicate that average number of events is generally higher in the six months after a riot than in the six months 
preceding a riot. This at first seems consistent a mobilizing effect of riots on nonviolent dissent. However, if there is a growth in protest activity leading up to the riot, then we may simply see more riots where we have more nonviolent protest. Since in many instances some extent of rioting can be observed during otherwise nonviolent protest and both can increase at the same time, the key question is whether there is plausible additional mobilization through riots or whether protest could have increased more without riots (or less rioting). This must be assessed by comparing to general trends in protest. Moreover, the increase in protest activity after riots appears to be relatively short-term and dissipate over the following months. This is in line with the idea that riots can ultimately undermine the growth of nonviolent mobilization.

Figure 1. Protest activity in months pre and post-riot

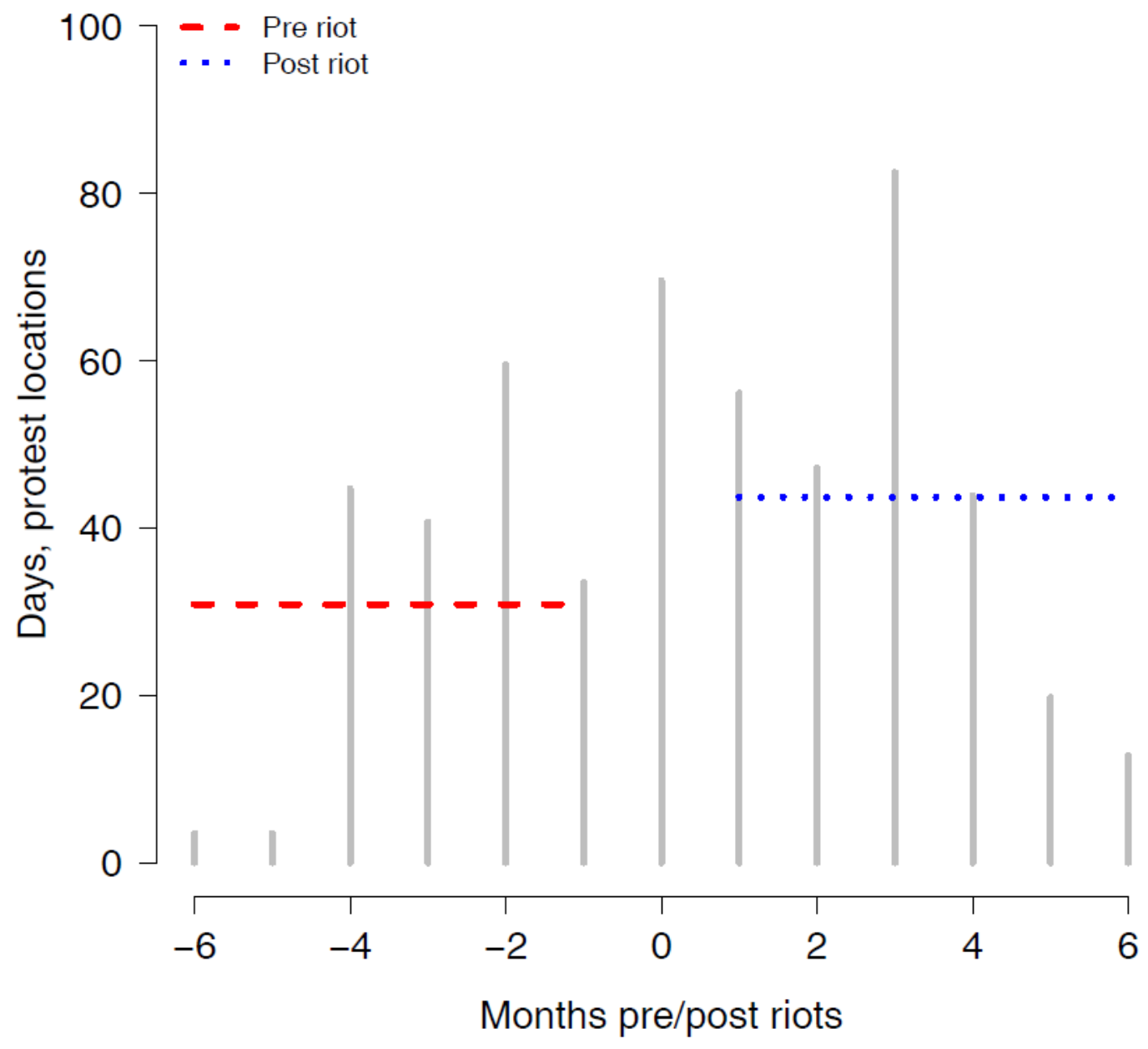


The fact that riots and protest often coexist makes it challenging to evaluate the relative weight of the potential positive and negative effects of riots and low-level violence on otherwise nonviolent mobilization. While we can explore the variation in the extent of rioting across cases of nonviolent mobilization, we cannot directly observe the counterfactual of what mobilization would have looked like without such incidents of rioting. We also lack good indicators of protest and riot intensity, as existing data rarely record the number of participants. The Social Conflict Analysis Data, for example, seeks to record the number of participants in events, but this information is missing for around $60 \%$ of the observations. Event count measures do not accurately reflect participation, as a higher count of small events could entail much lower net participation than a single large event (Biggs 2018: 352-353). Moreover, event count measures are also sensitive to the identification of individual events within larger campaigns and locations. These problems are compounded in many sources such as the SCAD data, as large events are often coded as a single nationwide event, whereas smaller confined events are counted individually. In this manuscript we focus on evaluating how the extent of observed rioting affect otherwise nonviolent protest by focusing on how they influence the likelihood of the initial emergence of large-scale nonviolent mobilization as well as their impact on the risk that ongoing nonviolent campaigns will collapse.

The rest of the manuscript is structured as follows. We first review existing research on violence in nonviolent campaigns, and how primarily nonviolent campaigns often see extensive incidental or unorganized violence. We then turn to the specific mechanisms linking incidental violence to campaign emergence and outcomes, detailing the possible negative and positive effects of rioting. We examine these propositions using data on riot events before the possible outbreak of mass nonviolence and during nonviolent campaigns. Our results suggest that riots generally have a detrimental effect on nonviolent mobilization, as we find that nonviolent campaigns are less likely to emerge after riots, once we consider the trend in level of protest 
activity. Moreover, even if riots may appear to increase campaign protest activity in the shortterm, riots ultimately make campaigns more likely to end. This is consistent with the claim that riots "scare off" potential participation and thus undermines the likelihood of massmobilization and accelerates the collapse of ongoing campaigns.

\section{Varieties of violence in nonviolent campaigns}

There are two main approaches to exploring nonviolent resistance. In the first approach, studies of civil resistance have found that nonviolent campaigns seem to succeed more often than armed campaigns, and more likely to see subsequent political change such as transitions to democracy (Chenoweth and Stephan 2011: 201-219; Rivera and Gleditsch 2013: 393-397). However, this research is often limited to comparing measures of success across organized nonviolent and armed campaigns rather than considering the emergence of nonviolent campaigns or dynamics of mobilization over time. This is important since many cases of initial protest and nonviolent mobilization, such as the case of Mozambique discussed above, fail to become a large-scale nonviolent campaign. Civil resistance literature also speaks less to the factors influencing the growth of mobilization and its sustainability over time, such as violence, (Butcher and Svensson 2016; Chenoweth and Ulfelder 2017).

Civil resistance literature largely classified individual dissident campaigns as either violent or nonviolent in a dichotomous manner, based on primary tactics that are deploy, thus largely exploring nonviolent and violent forms in isolation. A second approach, looking at social movements more broadly, insist that contentious politics often involves the sequencing of both violence and nonviolent dissent, and rejects the largely isolationist approach of civil resistance literature (e.g., Collins 2009; McAdam, Tarrow and Tilly 2001; della Porta and Diani 2006; Seferiades and Johnston 2012; Davenport 2014). Such scholars emphasize sequencing 
and substitution of tactics in contentious politics tend to emphasize explicit adoption of tactics, for example when movements turn to nonviolent direct action if conventional channels are blocked, or shift to other repertoires of resistance, i.e. organized rioting, sabotage or armed violence, if nonviolence proves ineffective or if violence is seen as justified in light of state repression (McAdam 1982; McAdam, Tarrow and Zald 1996; McAdam, Tarrow, Tilly 2001; della Porta and Diani 2006).

Nevertheless, to what extent sequencing is the case or a problem for conclusions ultimately depends on the type of dissent and the specific forms of violence we focus on. There are important conceptual differences in the types of violence that may arise during nonviolent dissent, based on the agents using force and the degree to which this is organized and coordinated. ${ }^{4}$ Dissent is often repressed, and it is conventional to delimit nonviolent dissent based on dissident tactics rather than government responses. ${ }^{5}$ Violence initiated by factions within a dissident campaign could be explicitly organized or coordinated, or unorganized actions without any active coordination or advance planning.

On the one hand, nonviolent dissident campaigns relatively infrequently turn into extensive organized violence or armed rebellion. Across our data, there are few cases where organizations deliberate switch from one tactic to the other, with notable exceptions being bestknown examples such as the African National Congress in South Africa (Asal et al. 2013: 306307; Chenoweth and Lewis 2013: 418-419). In Libya and Syria, organized armed violence emerged after initial nonviolent protest, and came to dominate other tactics, but emerged largely from defection from the government and the army rather than initial dissident groups changing tactics. Shifts to organized violence become slightly more common if we also include violent fringe groups and unconventional warfare such as terrorism, but organized violence 
remains relatively infrequent even by these more encompassing measurers (Belgioioso et al. 2019: 285; Dudouet 2013: 403).

On the other hand, less organized forms of violence such as riots or disorganized clashes with the police appear to be much more common during nonviolent protest campaigns. While incidental violence is common in many nonviolent campaigns, the impact of such violence on otherwise nonviolent protest and ongoing nonviolent campaigns remains poorly understood in both approaches. Existing civil resistance literature has not directly accounted for the impact of rioting and studies on violent flanks remain focused on organized and militarized armed groups. In contrast, social movement literature has extensively explored waves of contention and shifts between nonviolent and violent protest; where rioting represents an important shift in tactics, often emerging in response to state repression and emerging radicalism (Tarrow 1989; Traugott 1995; McAdam, Tarrow and Tilly 2001; Seferiades and Johnston 2012; della Porta and Fillieule 2004; della Porta and Diani 2006), Yet this literature also tells us little about the impact incidental violence has on the onset and fate of nonviolent resistance campaigns.

Social movement literature also makes assumptions about the level of organization within rioting that emerges during nonviolent resistance. ${ }^{6}$ Yet the lack of coordination and organization in most riots is not consistent with Tilly's (1986: 4) emphasis on repertoires as the range of means for "making claims". The SCAD data distinguishes between organized riots (with identifiable organizers) and spontaneous riots, in which $88 \%$ of recorded rioting fall in the second category.

A much more common form of violence during nonviolent campaigns is unorganized violence without planning or coordination such as individuals fighting with the police and riots. Bringing people together in mass nonviolent dissent creates situations that are potentially volatile. Individuals may resort to violence against police or security forces, without any prior 
planning or advance warning. Much of the violence during nonviolent campaigns, such as the incidents discussed in Mozambique, have been precisely such spontaneous acts often driven by emotions and outbursts of anger rather than clear political strategies or strategic goals (e.g., Seferiades and Johnson 2012: 12-13). It is very common that participants in a campaign start to fight with the police, or throw rocks or primitive incendiary devices, yet this is rarely coordinated or planned in advance. Collins (2009: 39-73) emphasizes how violence is often opportunistic, typically lashing out against weak, immediate and often random targets. Unorganized violence can be facilitated by the anonymity afforded in crowds, where individuals are less at risk of retribution. Disorganized violence faces much lower barriers than resorting to organized violence, as it does not require coordination, planning or entail future commitments. Sociological studies of violence such Collins (2009: 94) emphasize "confrontational tensions" and fear as an emotional state, where people often respond with generally disorganized and often incompetent acts of violence.

There is also an extensive literature on the origins of riots, who participates and the diffusion of riots, often focused on race riots in the US (e.g., Blau and Blau 1982; Mason and Murtagh 1985; Olzak 1987), historical protest behavior and riots in Europe or recent riots in cities such as London or Paris (e.g. Aidt et al. 2017; Aidt and Leon 2015; Kawalerowicz and Biggs 2015; Moran and Waddington, 2015; Newburn, 2016; Seferiades and Johnston 2012; della Porta and Fillieule 2004; della Porta and Diani 2006; Opp 2009). Some riots occur amid a backdrop of organized political dissent, but not all organized dissent evolves into large-scale campaigns, and most studies do not focus on how riots may affect nonviolent campaigns with maximalist claims on the government.

Despite the ambiguous impact of rioting, many activists also see rioting as disorganized from of violence and something to try to avoid rather than an explicit tactic in their arsenal 
(Popovic and Miller 2015: 195-214). Likewise, some case studies have concluded that the risk of disorganized violence poses a clear challenge for movements seeking to maintain nonviolent discipline and broad public support (Bhavnani and Jha 2014: 77-79; Pearlman 2011: 2). Building on activist accounts, civil resistance literature also broadly argues that nonviolent discipline is important tactic that promotes backfire; the reduction of state authority that deploys violent repression. For state repression to generate backfire, organizers of nonviolent resistance usually must avoid violent backlash to state repression (Pinckney 2016; 35-67; Martin 2007; 123-124; also see Sutton, Butcher and Svensson 2014).

This is something also highlighted by social movement literature, which argues the tactical interaction between protesters and oppressors are critical in determining backfire and changes in repertoire of dissent. For instance, the violent repression of the civil rights movement in the US was important in sustaining the movement and contributed to the intervention of federal soldiers (McAdam 1982). From this is the implicit suggestion that incidental violence is an important determinant of dynamics of nonviolent mobilization and whether nonviolent campaigns can successfully emerge and whether they can survive amid interactions with the state.

Yet, since existing research has largely focused on escalations to organized violent dissent and its interaction with otherwise nonviolent dissent, we have few insights into the consequences of unorganized violence for nonviolent mobilization. Focusing on the dissidents' primary tactics and the explicit shifts in primary campaign strategies during protest is in some ways akin to looking for the effects of violence under a well-lit but rather peripheral lamppost. Since unorganized violence such as riots or crowd violence are common during protests it is remarkable that there has not been more attention to their consequences for nonviolent 
mobilization. In the next section we turn to the challenges in starting and maintaining nonviolent campaigns, detailing potential negative and positive effects of incidental violence.

\section{Getting off the ground and sustaining a nonviolent campaign}

Maximalist political dissent seeks to challenge the government through imposing costs. Whereas violent dissent seeks to coerce a government through killing and the ramifications of violence, nonviolent dissent tries to force a government to make concessions using techniques such as nonviolent intervention, noncompliance, and persuasion. Effective nonviolent action depends on the ability of activists to mobilize large numbers of people (DeNardo 1985: 58-86; Chenoweth and Stephan 2011: 30-61; Schock 2005: 38-42). Nonviolent movements have more leverage to undermine the legitimacy of the state and its ability to rule when they can mobilize large numbers or demonstrate that they can garner broad support (Schock 2005:52-53; Nepstad 2015: 94). Of course, violent movements also benefit from more extensive participation, but they are less sensitive to a minimum threshold, and can often exert a non-trivial impact with limited participation.

Mobilizing people to participate at the outset of a nonviolent campaign is often extremely difficult. Large participation provides "safety in numbers" and allows participants to overcome fear and publicly express grievances they previously kept private (Pearlman 2016: 26-27). But nonviolent campaigns must initially manage to cross a critical minimum "participation threshold" and maintain numbers to have a notable political impact (Kuran 1991: 16-19; Lohmann 1994: 49-56). Mobilization and collective action hinges on individual perceptions that many others will also participate as well as maintaining high participation in the face of possible repression and the risk of sanctions and injury (Kuran 1991: 18). 


\section{How riots could undermine nonviolent mobilization}

Activists stress the need for movements to avoid violence and its potential detrimental effects for achieving large-scale popular participation. For example, widely-used training manuals developed for activists emphasize the role of strategy, unity, and nonviolent discipline in achieving large participation (Popovic and Miller 2015: 195-214, see also Martin 2007: 123124; Nepstad 2015: 92-97; Sharp 2005: 387-414). From this perspective, disorganized violence is antithetical to nonviolent discipline, and a threat to the ability of movements to achieve large participation and maintain unity throughout the campaign.

Extensive incidents of unorganized violence can damage nonviolent campaigns by alienating moderates and deter potential participants from joining the movement. Research on the negative impact of violent flanks often highlights how violence can discredit a campaign and make it more difficult to elicit defection by government supporters, which is often key to political success (Chenoweth and Schock 2015; Nepstad 2015; Sharp 2005: 397-414). Disorganized violence can undermine reaching the initial participation thresholds and maintaining participation. Despite the stereotype of contagious fights and bar brawls, people often respond with fear and flee when confronted with dangerous situations that entail a high risk of violence (Collins 2009: 10-19; Elster 2009: 57-62). Thus, extensive disorganized violence is likely to undermine initial mobilization and suppress subsequent participation, thereby promoting the collapse of campaigns.

Beyond the direct impacts on participation, disorganized violence may provoke and justify state repression against all challengers. Since repression is often indiscriminate and not limited to just rioters, fear of retribution can deter involvement by all potential participants. In Mozambique for example, state repression undermined nonviolent dissent from gaining momentum in both 2010 and 2012. Regimes often look for ways to discredit their opponent 
and justify state repression, and in some cases introduce agent provocateurs to instigate violence to help undermine a political campaign (Nepstad 2015: 98). Disorganized violence and riots make it less likely that security forces will disobey government orders and defect, and in turn also less likely that repression will backfire (Chenoweth and Schock 2015: 428; Chenoweth and Stephan 2011: 50-59). Finally, disorganized violence from violent fringe groups can alienate moderate allies (Wasow 2017: 8-9), particularly would-be participants from social groups closer to the regime, which undermines intergroup coalitions that are often essential to encouraging broader participation (Nepstad 2015: 91). If these arguments about the negative consequences of disorganized violence are correct, then we should expect more rioting to reduce the likelihood of initial large-scale nonviolent mobilization, and more likely that ongoing campaigns will collapse. From this we derive the first hypotheses:

H1a: Riots make the onset of a large-scale nonviolent anti-government campaign less likely.

H1b: Large-scale nonviolent anti-government campaigns are more likely to collapse following the presence of riots.

\section{The potential mobilizing effects of riots}

Although disorganized violence could have negative effects on nonviolent mobilization, a plausible opposing viewpoint holds that riots can mobilize nonviolent protest. Since riots and protest can occur at the same time, the two are clearly not inherently incompatible. Social movement literature suggests that forms of dissent are relational and can co-evolve over time as dissidents interact with each other, as well as with the police and other state apparatus. Increasing escalation and rioting may be purposeful tactics and evolving attempts at claim 
making amid rounds of repression, which may trigger further waves of nonviolent protest and greater participation (Tilly, 1986; Seferiades and Johnston 2012: 7-18; della Porta and Fillieule 2004: 233-235; della Porta and Diani 2006: 182-210). Moreover, the existing literature on the diffusion of riots suggests a number of potential mobilizing effects, as events in one location grow over time and spread in space to other locations (see Aidt et al. 2017; Aidt and Leon 2015; Kawalerowicz and Biggs 2015).

First, acts of disorganized violence can help draw attention to events, disseminate dissatisfaction to others in the target audience for mobilization, and heighten the sense of a crisis for the government (Ketchley 2017: 18-45). Disseminating such information is a key challenge in political mobilization. The barriers for participation are lowered when people see how dissatisfaction is widely shared and become more likely to believe that others will participate (Kuran 1991: 18; Lohmann 1994: 49). From this perspective, riots can "make news by making noise" or help generate momentum for a campaign (Thrall 2006: 417). Indeed, riots may draw more attention than purely nonviolent demonstrations, which government often ignore and potentially censored media do not report. Moreover, the emotional aspects of riots and perceived frustrations could help signal the depth of perceived injustice and the extreme steps that people are willing to take, in turn encouraging further participation (Seferiades and Johnston 2012: 14).

Second, disorganized violence and riots may unleash state repression, but repression can in some settings help nonviolent mobilization. Campaigns often involve a complex set of factions, and some have suggested that violent flanks can help generate an advantage for the moderate factions (Gamson, 1990: 81; Haines, 1988: 171; Piven and Cloward, 1988: 149-173). Riots during nonviolent campaigns may help moderate factions in a movement to distinguish themselves from violent factions and potentially divert repression away from the moderate 
factions (Chenoweth and Schock 2015: 428). Riots that arise in response to state repression may be perceived as justified, and repression could backfire in growing nonviolent mobilization rather than deterring participation (Ketchley 2017; Kadivar and Ketchley 2018: 3-4). Images of children throwing stones against Israeli armored vehicles during the first intifada, for example, helped to draw attention to the plight of the Palestinians and the magnitude of Israeli repression, and increased support for the campaign. In the United States, indiscriminate police responses to rioting during protest events are often seen as playing into the hands of activists calling for reform in law enforcement and the judicial system (Glaser and Sunstein 2015: 6-7). These arguments suggest two alternative hypotheses on the positive effects of riots:

H2a: Riots increase the likely onset of large-scale nonviolent anti-government campaigns.

H2b: Riots help sustain large-scale nonviolent mobilization meaning nonviolent antigovernment campaigns are less likely to collapse following incidents of rioting.

\section{Empirical Analysis}

We use two data sources to evaluate the competing hypotheses on the effects of riots on nonviolent campaigns. In our first analyses we consider the emergence of nonviolent campaigns involving maximalist nonviolent claims in a sample of 170 countries with a population over 500,000 (in 2010). ${ }^{7}$ We combine data on primarily nonviolent campaigns from the Nonviolent and Violent Campaigns and Outcome data (NAVCO, Chenoweth and Lewis 2013), which end in 2006, with information for 2007-2013 from the Major Episodes of Contention (MEC) data, an extension of the NAVCO data presented in Chenoweth and Ulfelder (2017: 310-312). We use the number of riots events in the previous year from the Cross-National Time Series Data Archive (CNTS), coded from reports by the New York Times 
(Banks and Wilson 2013). Riots are defined here as violent and physically forceful clashes involving at least 100 participants. We estimate a logit model of campaign onset given riots, with robust standard errors clustered on countries. Exploring a global dataset allows us to assess 166 onsets of nonviolent campaigns, and how rioting impacts the emergence of nonviolent campaigns in a global sample.

In our second set of analysis we assess campaign termination as a measure of the sustainability of campaigns. We consider the impact on termination from riot events in the Social Conflict Analysis Database (SCAD, Salehyan et al. 2012) that occur during an active nonviolent campaign in Africa and Central America between 1990 and 2013. The fact that SCAD provides information on the specific dates of riot events, enables us to look at a much more detailed timeline of rioting preceding the potential collapse of a campaign at the monthly level. ${ }^{8}$ We use a Cox proportional hazard model to estimate the influence of rioting upon the hazard rate of the termination of a campaign. Out of the 40 campaigns in our sample, 36 terminate before 2013 .

It would be ideal to have detailed data on the scale of protest to trace the effects of riots, but existing data have at best imperfect measures of protest magnitude. The most useful direct measure, the number of participants, is only available as an ordinal scale in orders of magnitude in the NAVCO data, and as a peak figure for each year. SCAD in principle includes data on participation in events, but this is missing in practice for about $60 \%$ of the events. Relying on the counting of protest events as a proxy for participation is problematic. There is no clear theoretical relationship between the number of events and the number of participants in the events - a count of three small event with 25 participants could appear larger than a single event with 1000 participants, the correspondence between the recorded number of events and participation is low in existing sources (Biggs 2018: 353). Moreover, the problems are 
compounded by often ambiguous rules for delineating events. We thus focus on how riots affect onset and termination of major nonviolent campaigns with participation thresholds of at least 1,000 people, as these data are at least better defined and have better coverage than the limited information on the number of participants.

We use different units of analysis and riot measures in the two analyses given the data coverage and the relative pros and cons of the sources. The CNTS riot measure is available for a larger period, but only as annual counts, without precise dates. The more fine-grained SCAD data allow us to consider the sequence and timing of events in detail in our analysis of campaign termination, and SCAD distinguishes between four distinct types of riots, based on their potential relationship to protest and motivation. We use a measure all riots that combines SCAD riot events that specifically start out as riots (fringe riots) and events that escalate from protest into rioting (which we label as escalatory rioting). We then consider riots which specially target the government, followed by separate analyses of government targeted fringe riots and escalatory riots. ${ }^{9}$ However, the fact that SCAD data are limited to countries in Africa and Central America and the $1990-2013$ period limits this analysis to 40 campaigns (37 of which emerge during this period). The SCAD data records 1139 riots across 271 campaign months, while 772 campaign months see no riot events.

It would also be ideal to consider the number of participants in riots, but we have similar problems here as for protest size. Although SCAD reports participation for some riots, this is missing for almost $70 \%$ of the observations. Counting events is further complicated by the location information, as $16 \%$ of the riot events in SCAD are classified as "nationwide", "regional", or "unknown" location. The nationwide events are often major riots or events in many simultaneous locations, yet counted as a single event. Counting these as one and "less significant" than a series of more easily differentiable events in distinct locations could be 
severely misleading (see Biggs 2018: 353). Abbs (2019) proposes a procedure to estimate event counts for nationwide and regional events based on the most likely locations, using other event characteristics, which we adapt here. He notes that the vast majority of SCAD geocoded riot and protest events occur in cities with a population over 100,000. "Nationwide" riots are assumed to be occurring in the capital and the country's five largest cities, if above 100,000 inhabitants. Regional events are coded as occurring in the five largest cities in the region. ${ }^{10}$

We control for a number of other features plausibly associated with nonviolent campaign onset or termination and the likelihood of rioting. First, we control for a number of important demographic, economic and political variables. This includes controls for logged population and logged GDP per capita (World Bank, 2016). Larger countries are likely to see nonviolent action and rioting than smaller countries, while in poorer countries, poverty may create motives for protest and rioting and governments tend to be weaker and have less capacity to deter unrest. We also control for the share of urban population (World Bank, 2016), since urbanization facilitates mobilization by reducing coordination and communication costs and potentially riots as well (Goldstone 1991; Wallace 2013).

We also consider the potential mobilizing effect of elections (e.g., Bunce and Wolchik 2011), using information from the National Elections across Democracy and Autocracy data (Hyde and Marinov 2012), and regime type using the Polity democracy scale. Political institutions may be associated with both incentives and prospects for nonviolent mobilization and rioting (Marshall et al. 2017). Moreover, non-democracies provide more motives for protest, but authoritarian regimes are more likely to repress opportunities for mobilization (Chenoweth and Ulfelder 2017).

Next we control for time dependences, by time since the last onset of a campaign and cubic splines to allow for a non-linear relationship (Beck and Katz, 2011). In the country-level 
analysis on campaign onset we also consider the number of CNTS anti-government demonstrations and strikes in the previous year to capture the growth in initial mobilization. ${ }^{11}$

Finally, we control for violence that occurs outside of the nonviolent campaign. This includes controls for state repression, which may be correlated with riots and have a mobilizing effect, even if intended to make dissent more costly and deter dissent (Sharp 2005; Sutton, Butcher and Svensson 2014). For the campaign onset analysis we use the Varieties of Democracy (V-Dem) Physical Integrity Rights Index (Coppedge et al., 2017), which provides full coverage for our sample. In the campaign termination analysis we use a more fine grained measure of repression, namely the ratio of SCAD events met with repression in the prior month, including separate indicators for nonlethal and lethal repression.

In the termination analysis we also consider possible regional differences between campaigns in Africa and campaign in Central America and the Caribbean, and control for organized violence that can occur during a nonviolent campaign. We include the number of terrorist attacks carried out by nonstate actors, taken from the Global Terrorism Database (GTD) (START 2012), and the number of armed conflict incidents using the Uppsala Conflict Data Program’s Georeferenced Event Dataset (Sundberg and Melander 2013).

\section{Nonviolent campaign onset}

We first evaluate the impact of rioting on nonviolent campaigns onset. H1a stipulates that since unorganized violence tends to "scare off" potential participants, we should be less likely to see a large-scale campaign starting after rioting. By contrast, if riots and unorganized violence has a mobilizing effect, as stated by the competing proposition $\mathrm{H} 2 \mathrm{a}$, then we should see a higher likelihood of a nonviolent campaign onset following riots. 
Table 1 displays the results for the logistic regressions of campaign onset. In Model 1 we simply consider the count of riots at $\mathrm{t}-1$, without other control variables. With this specification, rioting at t-1 appears to be positively associated with the likelihood of a major campaign starting in the subsequent year $(\mathrm{t})$. This seems consistent with hypothesis $\mathrm{H} 2 \mathrm{a}$ and a mobilizing effect of riots, indicating how people are "ticked off". However, we think this specification is flawed, as it does not consider the mobilizing effect of previous protest and the potential common trending in riots and growing protest activity. In Model 2 we consider a model with all the control variables and prior protest activity at $\mathrm{t}-1$. It is clear that more protests at t-1 goes together with a higher likelihood that we will see a major nonviolent campaign at $t$.

The results for the control variables in Model 2 are generally consistent with previous research; we find that nonviolent campaigns are more likely to emerge in more urbanized countries, with larger populations, and during election years. Nonviolent campaigns are more likely in more urbanized countries, and actually appear to be less likely the higher a country's per capita income. Finally, campaigns are less likely when the V-Dem physical integrity index is lower, indicating higher state repression, i.e. greater use of torture and more political killings.

In Model 3 we show that the apparent positive effects of riots at $\mathrm{t}-1$ on mobilization shrinks strongly towards 0 when we consider control variables, and is no longer statistically significant. More dramatically, we show in Model 4 that when we also include the level prior protest in Model 4 to account for trending in protest - which may be also associated with riots - the coefficient estimate for riots at (t-1) turns negative and statistically significant. This is consistent with hypothesis H1a, postulating that a major nonviolent campaign is less likely after rioting, since rioting "scares off" potential participants in a major nonviolent campaign. ${ }^{12}$

Note that we control for repression through the V-Dem physical integrity index, and as such the negative effect for riots cannot be seen as simply reflecting that repression after riots 
suppresses protest. We further assess this potential mediating effect in our models by exploring the interaction effect of rioting and state repression (see Table 3 in the Appendix - model 9). This interaction has no significant effect on the onset of nonviolent campaigns. Even when including this interaction in the model, the results remain the same. While there is interplay between rioting, repression and nonviolent protest, the impact of rioting on the onset of a nonviolent campaign is not dependent on the presence of state repression.

Table 1. Logistic regressions - rioting and the onset of nonviolent campaigns

\begin{tabular}{|c|c|c|c|c|}
\hline & $\begin{array}{c}(1) \\
\text { Onset NVC } \\
(\mathrm{MEC})\end{array}$ & $\begin{array}{c}(2) \\
\text { Onset NVC } \\
(\mathrm{MEC}) \\
\end{array}$ & $\begin{array}{c}\text { (3) } \\
\text { Onset NVC } \\
\text { (MEC) }\end{array}$ & $\begin{array}{c}\text { (4) } \\
\text { Onset NVC } \\
(\mathrm{MEC}) \\
\end{array}$ \\
\hline Riot Events (Banks) t-1 & $\begin{array}{c}0.106 * * * \\
(0.022)\end{array}$ & & $\begin{array}{c}0.021 \\
(\mathbf{0 . 0 3 0})\end{array}$ & $\begin{array}{l}-0.086^{*} \\
(0.041)\end{array}$ \\
\hline Protest Events (Banks) t-1 & & $\begin{array}{c}\mathbf{0 . 1 2 4} * * * \\
(0.029)\end{array}$ & & $\begin{array}{c}0.169 * * * \\
(0.034)\end{array}$ \\
\hline National Population (log) & & $\begin{array}{c}0.303 * * * \\
(0.061)\end{array}$ & $\begin{array}{c}0.356 * * * \\
(0.058)\end{array}$ & $\begin{array}{c}0.318 * * * \\
(0.063)\end{array}$ \\
\hline Urban Population (\%) & & $\begin{array}{c}0.027 * * * \\
(0.008)\end{array}$ & $\begin{array}{c}0.028 * * * \\
(0.008)\end{array}$ & $\begin{array}{c}0.026^{* * *} \\
(0.008)\end{array}$ \\
\hline GDP per Capita (log) & & $\begin{array}{l}-0.566 * * * \\
(0.149)\end{array}$ & $\begin{array}{c}-0.554 * * * \\
(0.149)\end{array}$ & $\begin{array}{l}-0.572 * * * \\
(0.150)\end{array}$ \\
\hline Polity2 & & $\begin{array}{l}-0.004 \\
(0.018)\end{array}$ & $\begin{array}{l}-0.001 \\
(0.018)\end{array}$ & $\begin{array}{l}-0.002 \\
(0.018)\end{array}$ \\
\hline Election Year & & $\begin{array}{l}0.582 * * \\
(0.182)\end{array}$ & $\begin{array}{c}0.590 * * \\
(0.180)\end{array}$ & $\begin{array}{c}0.587 * * \\
(0.183)\end{array}$ \\
\hline $\begin{array}{l}\text { V-Dem Physical Integrity } \\
\text { Index }\end{array}$ & & $\begin{array}{l}-0.808+ \\
(0.466)\end{array}$ & $\begin{array}{l}-0.845+ \\
(0.464)\end{array}$ & $\begin{array}{l}-0.815+ \\
(0.470)\end{array}$ \\
\hline Years since last NVC & & $\begin{array}{l}-0.165^{*} \\
(0.075)\end{array}$ & $\begin{array}{c}-0.220 * * \\
(0.074)\end{array}$ & $\begin{array}{l}-0.168^{*} \\
(0.074)\end{array}$ \\
\hline Spline1 & & $\begin{array}{l}-0.002+ \\
(0.001)\end{array}$ & $\begin{array}{l}-0.002^{*} \\
(0.001)\end{array}$ & $\begin{array}{l}-0.002+ \\
(0.001)\end{array}$ \\
\hline Spline2 & & $\begin{array}{c}0.001 \\
(0.001)\end{array}$ & $\begin{array}{l}0.001+ \\
(0.001)\end{array}$ & $\begin{array}{c}0.001 \\
(0.001)\end{array}$ \\
\hline Spline3 & & $\begin{array}{l}-0.000 \\
(0.000)\end{array}$ & $\begin{array}{l}-0.000 \\
(0.000)\end{array}$ & $\begin{array}{l}-0.000 \\
(0.000)\end{array}$ \\
\hline Constant & $\begin{array}{l}-3.834 * * * \\
(0.118)\end{array}$ & $\begin{array}{c}-5.148 * * * \\
(1.414)\end{array}$ & $\begin{array}{c}-5.747 * * * \\
(1.348)\end{array}$ & $\begin{array}{l}-5.285 * * * \\
(1.406)\end{array}$ \\
\hline Observations & 5825 & 5822 & 5822 & 5822 \\
\hline Log likelihood & -621.973 & -568.181 & -574.848 & -566.461 \\
\hline Chi-squared & 23.26 & 150.078 & 118.857 & 157.129 \\
\hline Pseudo R2 & 0.007 & 0.093 & 0.083 & 0.096 \\
\hline
\end{tabular}




\section{Riots and campaign termination}

We now turn to the effects of riots on the hazard of nonviolent campaign termination. If incidental violence "scares off" participants and alienates potential supporters, as suggested by $\mathrm{H} 1 \mathrm{~b}$, then we should see an increased likelihood of nonviolent campaign termination following riots. However, if violence has a mobilizing effect, as postulated by $\mathrm{H} 2 \mathrm{~b}$, termination should become less likely following incidents of rioting. We evaluate these competing arguments about the effects of riots on campaign termination through a series of Cox proportional hazard models, where we also consider the other covariates that may influence both rioting and the likelihood of campaign termination.

Table 2 reports the estimates for a series of different model specifications using different riot measures. We lag all time-varying covariates by one month, and report robust standard errors clustered by countries. The Cox proportional hazard model indicates how covariates affect the underlying baseline hazard, without assuming a specific form for the baseline hazard. Hence, a positive coefficient in the model estimates indicates that a covariate is associated with a higher hazard of campaign termination, while a negative coefficient indicates a lower hazard of campaign termination, which in turn leads to longer expected campaigns.

In Models 6-8 we disaggregate the overall riot variable into specific subtypes in order to examine if different types of riots may have substantively different effects. We distinguish between riots that specifically target the government, which could be seen as the riots which exhibit the clearest political motivation (Model 6), fringe events that start out as a riot, and which may simply occur alongside a nonviolent campaign (Model 7), and escalatory rioting, which originates and escalate from a protest event, but may be less coordinated or connected to an ongoing campaign (Model 8). 
Table 2. Cox proportional hazard models - duration and termination of nonviolent campaigns

\begin{tabular}{|c|c|c|c|c|}
\hline & $\begin{array}{c}\text { (5) } \\
\text { Campaign } \\
\text { Termination }\end{array}$ & $\begin{array}{c}\text { (6) } \\
\text { Campaign } \\
\text { Termination }\end{array}$ & $\begin{array}{c}\text { (7) } \\
\text { Campaign } \\
\text { Termination }\end{array}$ & $\begin{array}{c}(8) \\
\text { Campaign } \\
\text { Termination } \\
\end{array}$ \\
\hline All Riots (t-1) & $\begin{array}{l}0.112 * * \\
(0.034)\end{array}$ & & & \\
\hline Govt. Targeted Riots (t-1) & & $\begin{array}{c}0.116 * * \\
(0.042)\end{array}$ & & \\
\hline Fringe Riots Only (t-1) & & & $\begin{array}{c}0.132 * * \\
(\mathbf{0 . 0 4 3 )}\end{array}$ & \\
\hline Escalatory Riots Only (t-1) & & & & $\begin{array}{c}0.209 * * \\
(0.068)\end{array}$ \\
\hline Population - logged (t-1) & $(0.376)$ & $\begin{array}{l}-0.464 \\
(0.381)\end{array}$ & $\begin{array}{l}-0.456 \\
(0.365)\end{array}$ & $\begin{array}{l}-0.478 \\
(0.371)\end{array}$ \\
\hline $\begin{array}{l}\text { Urban Population }(\%) \\
(\mathrm{t}-1)\end{array}$ & $\begin{array}{l}-0.004 \\
(0.033)\end{array}$ & $\begin{array}{c}0.003 \\
(0.033)\end{array}$ & $\begin{array}{c}0.004 \\
(0.032)\end{array}$ & $\begin{array}{l}-0.006 \\
(0.035)\end{array}$ \\
\hline $\begin{array}{l}\text { GDP per Capita - logged } \\
(\mathrm{t}-1)\end{array}$ & $\begin{array}{c}0.122 \\
(0.634)\end{array}$ & $\begin{array}{l}-0.036 \\
(0.599)\end{array}$ & $\begin{array}{l}-0.041 \\
(0.610)\end{array}$ & $\begin{array}{c}0.159 \\
(0.619)\end{array}$ \\
\hline Polity2 (t-1) & $\begin{array}{c}0.075 \\
(0.056)\end{array}$ & $\begin{array}{c}0.081 \\
(0.055)\end{array}$ & $\begin{array}{c}0.078 \\
(0.056)\end{array}$ & $\begin{array}{c}0.070 \\
(0.052)\end{array}$ \\
\hline Africa (Regional Dummy) & $\begin{array}{c}0.774 \\
(0.554)\end{array}$ & $\begin{array}{c}0.653 \\
(0.550)\end{array}$ & $\begin{array}{c}0.703 \\
(0.538)\end{array}$ & $\begin{array}{c}0.714 \\
(0.562)\end{array}$ \\
\hline Elections $(\mathrm{t}-1)$ & $\begin{array}{c}0.486 \\
(0.392)\end{array}$ & $\begin{array}{c}0.439 \\
(0.377)\end{array}$ & $\begin{array}{c}0.457 \\
(0.385)\end{array}$ & $\begin{array}{c}0.478 \\
(0.384)\end{array}$ \\
\hline $\begin{array}{l}\text { Ratio of Nonlethal Repression } \\
\text { - SCAD (t-1) }\end{array}$ & $\begin{array}{c}0.192 \\
(0.575)\end{array}$ & $\begin{array}{c}0.138 \\
(0.570)\end{array}$ & $\begin{array}{c}0.142 \\
(0.554)\end{array}$ & $\begin{array}{l}0.173 \\
(0.574)\end{array}$ \\
\hline Ratio of Lethal Repression & $2.141 * *$ & $2.102 * *$ & $1.950 * *$ & $2.516 * *$ \\
\hline Terrorism Events - GTD (t-1) & $\begin{array}{c}0.048) \\
0.271 * * \\
(0.062)\end{array}$ & $\begin{array}{c}0.301 * * \\
(0.060)\end{array}$ & $\begin{array}{c}(0.080) \\
0.317 * * \\
(0.060)\end{array}$ & $\begin{array}{c}(0.580) \\
0.293 * * \\
(0.051)\end{array}$ \\
\hline $\begin{array}{l}\text { Armed Conflict Events - UCDP GED } \\
(\mathrm{t}-1)\end{array}$ & $\begin{array}{l}-0.138 \\
(0.402)\end{array}$ & $\begin{array}{l}-0.180 \\
(0.498)\end{array}$ & $\begin{array}{l}-0.103 \\
(0.368)\end{array}$ & $\begin{array}{l}-0.633 \\
(0.760)\end{array}$ \\
\hline Observations & 964 & 964 & 964 & 964 \\
\hline NVC Terminations & 36 & 36 & 36 & 36 \\
\hline Log likelihood & -72.799 & -75.090 & -74.780 & -74.843 \\
\hline Chi-squared & 53.429 & 44.925 & 52.042 & 43.055 \\
\hline
\end{tabular}

In Model 5 we first consider a compound term for all types of rioting in SCAD (both government and non-government targets) on campaign termination. We find a positive and significant coefficient estimate, indicating that riots generally increase the likelihood of campaign termination. This is consistent with the argument that the dominant effect of incidental violence is to undermine nonviolent campaigns. However, it is contrary to the claim 
that riots tend to have a mobilizing effect on sustaining protest. At a minimum, a campaign must remain active to have some political impact, and riots appear to make this less likely.

Few of the control covariates appear to have consistent effects on the likelihood of campaign termination. The Polity democracy measure is positive and marginally significant in some specifications. But the only control variables that are consistently significant are lethal repression and terrorism events. Violence from state repression and terrorist non-state actors are associated with a higher rate of termination. By controlling for these we can ensure that the estimated impact of rioting does not reflect effects of organized violence.

Controlling for state repression also does not impact the results concerning any of the riot variables, thus the negative impact of rioting during a nonviolent campaign is not reflection of state suppression after rioting has occurred. We also find no evidence of a possible interaction effect between repression and rioting during nonviolent campaigns (see Table 3 in the appendix - models 10-13). Rioting undermines the momentum of nonviolent campaigns, but this effect is independent of and not dependent on the existence of state repression.

Figure 2. Coefficient plots for riot terms in Table 2

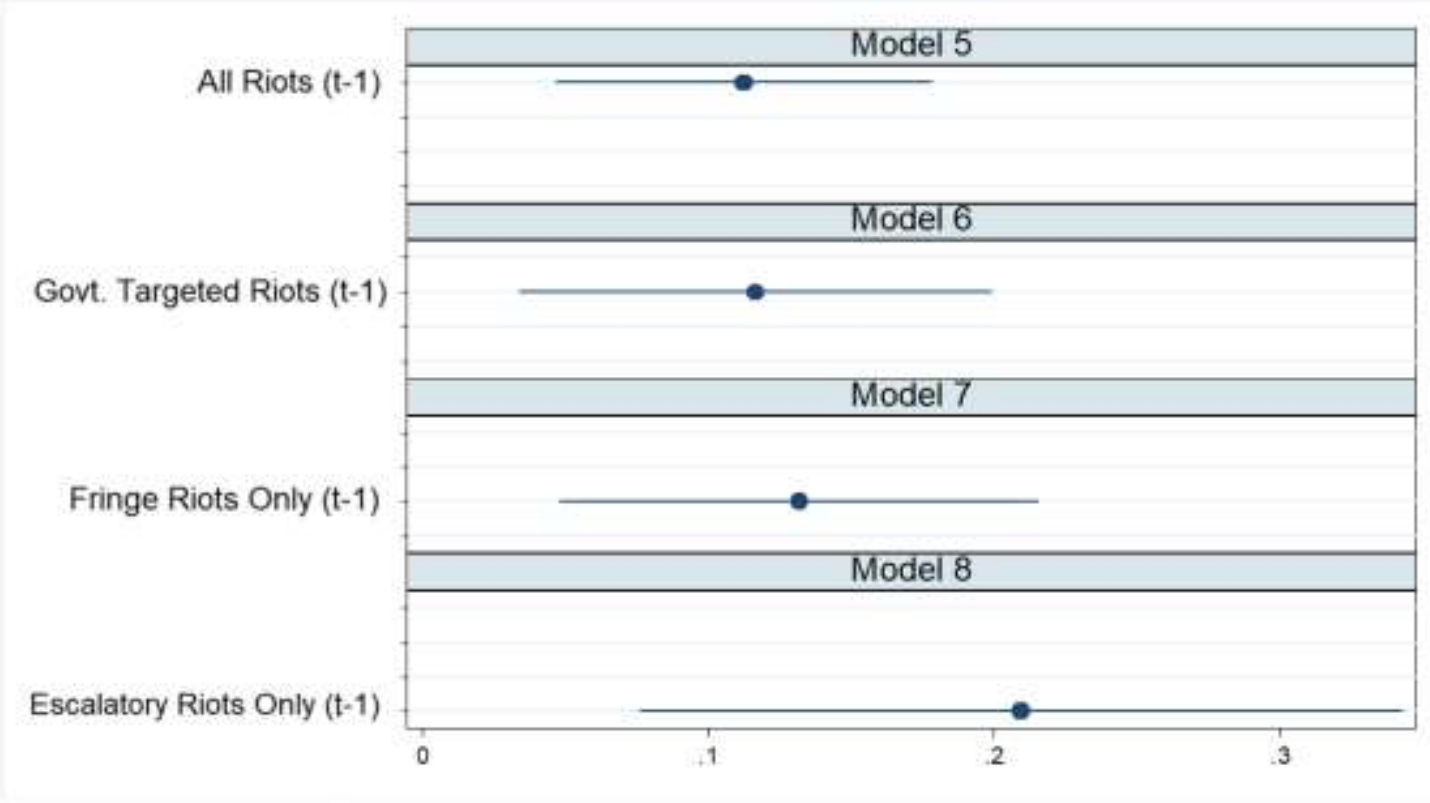


It is clear from Figure 2 that all the estimated riot coefficients are consistently positive. Moreover, measures of model fit in Table 2 do not suggest that any one of the models, with the specialized riot, measures fit the data notably better than the model with the compound riots measure. The fact that the coefficient for initially nonviolent protest escalating into riots is the largest could be seen as support for the idea that violent flanks within nonviolent movements are most likely to precede nonviolent campaign collapse, but there is little evidence for any clear differential impacts of different types of riots, since all types of riots consistently increase the likelihood that a campaign will end. ${ }^{13}$ In general, the results here are consistent with the claim idea that riots and disorganized violence scare people off and undermine the viability of movements.

It could be argued that campaign termination is ambiguous outcome, since campaigns could end both due to internal failures of a movement or changes in the context motivating the campaign - i.e., if a government makes concessions. The strong correlation between campaign duration and the cumulative likelihood of riots over the course of a campaign means that many campaigns classified as successful in NAVCO see riots at some point. NAVCO 2.0 provides measures intended to code whether campaigns are successful or not, although these only covers up until 2006 and we have no such information in the MEC data for the subsequent period. We find no evidence that full success campaigns are systematically shorter, nor that rioting is more common in the fully successful campaigns; rioting is more common in successful campaigns (35.3\% of campaign months) than in unsuccessful campaigns ( $24.8 \%$ campaign months). Thus, we do not think that riots lead to higher rates of success and or that the type of termination provides a plausible rival interpretation for our findings. 


\section{Conclusion and discussion}

Disorganized violence such as riots often occur alongside nonviolent protest, but previous research provides few clues as to how riots may influence political mobilization. We provide what is to our knowledge the first analysis of how riots affect the likelihood of nonviolent mass mobilization and the sustainability of nonviolent campaigns. We note the divergent pessimistic expectations of activists, who tend to emphasize the detrimental effects for nonviolent movements, with the potential mobilizing effect, where riots are seen as helping to promote protest and mobilize further dissent by showing how many within society are "ticked off".

Our findings point strongly towards riots having generally negative effects on nonviolent activism, in line with the argument that riots tend to "scare off" potential participants, thus undermining the prospects for large campaigns and increasing the likelihood that ongoing campaigns will collapse. The apparent mobilizing effects of riots are illusory, and reflect that riots often increase in scale with more protest. The partial effect of riots and the long-run consequences appear to be consistently negative when we consider both the scale of prior riots and protest. Converting nonviolent mobilization into a long-term campaign is better helped by maintaining nonviolent discipline and preventing riots rather than trying to capitalize on them, and movements are unlikely to see substantial growth in participation from rioting alone. Riots do not necessarily kill all campaigns immediately, but they do entail a higher risk of campaigns ending in the short run, in line with the concerns expressed by activists. In short, disorganized violence is likely to be far less threatening to leaders than organized nonviolent protests, and the fact that government often try to instigate violence during nonviolent dissent suggests that they understand how this can help "scare off" potential participants. For this reason, governments are unlikely to be particularly afraid of riots, despite their potentially uncontrollable nature, but have good reasons to fear organized and growing nonviolent protest. 
Our findings here also help to account for the divergent outcomes of nonviolent campaigns and suggest that rioting can be an important and leading indicator of failing campaigns, as seen in the events in Iran during late 2017 and early 2018. The protests that began in the city of Mashhad on 28 December 2017 quickly spread to other cities and became the largest challenge to the regime since the Green Revolution protests after the disputed elections in 2009. However, while the 2009 uprising lasted for months, and eventually encompassed more than a million active participants, the $2017-18$ protests saw much lower participation and started to decline after just one week. The extent of rioting and property damage allowed the government to justify a strong repressive response, and likely alienated many plausible would-be protesters. A better coordinated movement could have helped prevent disorganize violence and attract broader participation, thus making it harder for the government to undermine the legitimacy of the protests.

Our analyses are suggestive about the detrimental consequences of riots for large-scale nonviolent resistance, but we also acknowledge the limitations of our analysis. In particular, since we lack direct measures of participation, it is difficult to trace in more detail the short and long-term impact of riots. This is in principle possible to do with more detailed time series analysis for individual countries, although there is likely to be great deal of variation from one country to another, and thus important to consider to what extent individual countries trajectories are likely to be representative for general trends and patterns. Moreover, we are not able to directly evaluate individual responses to riots in our current analysis - that is, whether riots genuinely have more impact on "scaring off" potential individual participants than helping to convey how others are "ticked off" and willing to take extreme measures, despite the potential risks. It may be possible to evaluate these mechanisms more directly using public opinion data and experimental approaches. 
Finally, we also concede that the consequences of unorganized violence and riots can also depend on a host of other issues, such as framing, as well as the broader competitive interactions surrounding dissent. In some cases, a government can successfully discredit a nonviolent movement by highlighting incidental violence as demonstrating the true "violent" and disorderly character, as appears to have been successful in the case in Iran. However, movements may be more resilient if they can successfully "counterframe", and place the blame more directly on the government, and riots are seen as resulting from justified outrage, even if the method itself is not condoned. Here again it may be possible to devise experimental tests to provide a way to test the importance of such strategies directly. However, this study clearly demonstrates the importance of riots and unorganized violence for nonviolent dissent and its outcomes. The important challenges that this can create for both dissident movements and governments should be central to the future research agenda on protest and dissent. 


\section{References}

Abbs, L. 2020. "The Hunger Games: Food Prices, Ethnic Cleavages and Nonviolent Action in Africa." Journal of Peace Research 57 (2): 281-296.

Aidt, T.S., G. Leon and M. Satchell. 2017. "The Social Dynamics of Riots: Evidence from the Captain Swing Riots, 1830-31." Typescript, University of Cambridge, available at http://sticerd.1se.ac.uk/seminarpapers/pspe02052017.pdf.

Aidt, T.S. and G. Leon. 2015. "The Democratic Window of Opportunity: Evidence from Riots in Sub-Saharan Africa.” Journal of Conflict Resolution 60(4):694-717.

Asal, V., R. Legault, O. Szekely and J. Wilkenfeld. 2013. "Gender Ideologies and Forms of Contentious Mobilization in the Middle East.” Journal of Peace Research. 50(3): 305318.

Banks, A.S., and K.A. Wilson. 2018. Cross-National Time-Series Data Archive. Databanks International. Jerusalem, Israel. https://www.cntsdata.com/.

BBC. 2010. "Deadly Riots in Mozambique over Rising Prices. BBC News, $1^{\text {st }}$ September 2010." http://www.bbc.co.uk/news/world-africa-11150063.

Beck, N., and J.N. Katz. 2011. "Modeling Dynamics in Time-Series-Cross-Section Political Economy Data." Annual Review of Political Science, 14: 331-352.

Belgioioso, M., K.S. Gleditsch, and D. Vidovic. 2019. "A Tale of Two Governments? Government Responses and Perceived Influence in the 2014 Protests in Bosnia and Herzegovina." Journal of Global Security Studies, 3(3): 285-301.

Bhavnani, R., and S. Jha. 2014. "Gandhi's Gift: Lessons for Peaceful Reform from India's Struggle for Democracy." The Economics of Peace and Security Journal, 9(1): 76-88.

Biggs, M. 2018. "Size Matters: Quantifying Protest by Counting Participants." Sociological Methods and Research, 47(3): 351-383.

Blau, J.R., and P.M. Blau. 1982. "The Cost of Inequality: Metropolitan Structure and Violent Crime.” American Sociological Review, 47(1): 114-129.

Bunce, V.J., and S.L. Wolchik. 2011. Defeating Authoritarian Leaders in Postcommunist Countries. Cambridge: Cambridge University Press.

Butcher, C., and I Svensson. 2016. "Manufacturing Dissent Modernization and the Onset of Major Nonviolent Resistance Campaigns.” Journal of Conflict Resolution, 60(2): 311339. 
Chenoweth, E., \& Stephan M.J. 2011. Why Civil Resistance Works: The Strategic Logic of Nonviolent Conflict. New York, NY: Columbia University Press

Chenoweth, E., and O.A. Lewis. 2013. "Unpacking Nonviolent Campaigns: Introducing the NAVCO 2.0 Dataset." Journal of Peace Research, 50(3): 415-423.

Chenoweth, E., and K. Schock. 2015. "Do Contemporaneous Armed Challenges Affect the Outcomes of Mass Nonviolent Campaigns?" Mobilization 20(4):427-451.

Chenoweth, E. and J. Ulfelder. 2017. "Can Structural Conditions Explain the Onset of Nonviolent Uprisings?” Journal of Conflict Resolution, 61(2): 298-324.

Collins, R. 2009. Violence: A Micro-sociological Theory. Princeton: Princeton University Press.

Coppedge, M., J. Gerring, S.I. Lindberg, S-E. Skaaning, J. Teorell, D. Altman, M. Bernhard, M.S. Fish, A. Glynn, A. Hicken, C.H. Knutsen, J. Krusell, A. Lührmann, K.L. Marquardt, K. McMann, V. Mechkova, M. Olin, P. Paxton, D. Pemstein, J. Pernes, C.S. Petrarca, J. von Römer, L. Saxer, B. Seim, R. Sigman, J. Staton, N. Stepanova, and S. Wilson. 2017. V-Dem [Country-Year/Country-Date] Dataset v7.1 Varieties of Democracy (V-Dem) Project.

de Brito, L.; E. Chaimite, C. Pereira, L. Posse, M. Sambo and A. Shankland. 2014. "Hunger Revolt and Citizen Strikes: Popular protests in Mozambique, 2008-2012." Brighton \& Maputo: Institute of Development Studies \& Instituto de Estudos Sociais e Económicos. https://www.ids.ac.uk/publication/hunger-revolts-and-citizen-strikes-popular-protestsin-mozambique-2008-2012.

della Porta, D. and O. Fillieule. 2004. "Policing Social Protest" In A. Snow, S.A. Soule and H. Kriesi (Eds.). The Blackwell Companion to Social Movements. Oxford: Blackwell Publishing.

della Porta, D and M. Diani. 2006. "Social Movements: an Indroduction (2nd Eds.)." Oxford: Blackwell Publishing.

della Porta, D. 2013. Clandestine Political Violence. Cambridge: Cambridge University Press.

DeNardo, J. 1985 Power in Numbers: The Political Strategy of Protest and Rebellion. Princeton: Princeton University Press.

Dudouet, V. 2013. "Dynamics and Factors of Transition from Armed Struggle to Nonviolent Resistance.” Journal of Peace Research, 50(3): 401-413.

Davenport, C. 2007. "State Repression and Political Disorder." Annual Review of Political Science, 10: 1-23.

Davenport, C. 2014. How Movements Die. Cambridge: Cambridge University Press. 
Elster, J. 2009. "Emotions." In P. Hedstrom and P. Bearman (Eds.). The Oxford Handbook of Analytical Sociology. Oxford: Oxford University Press.

Gamson, W.A. 1990. The Strategy of Social Protest. Belmont: Wadsworth.

Glaser, E.L. and C.R. Sunstein. 2015. “A Theory of Civil Disobedience.” Unpublished manuscript, Harvard University, Faculty Research Working Paper Series.

Gleditsch, K.S.; R.G. Olar, and M. Radean. 2017. "Going, Going, Gone? Varieties of Dissent and Leader Exits." Unpublished manuscript, University of Essex.

Goldstone, J.A. 1991. Revolution and Rebellion in the Early Modern World. Berkeley: University of California Press.

Haines, H.H. 1988. Black Radicals and the Civil Rights Mainstream, 1954-1970. Knoxville: University of Tennessee.

Hyde, S.D., and N. Marinov. 2012. "Which Elections Can Be Lost?" Political Analysis 20(2):191-201.

Kadivar, M.A. and N. Ketchley. 2018. "Sticks, Stones, and Molotov Cocktails: Unarmed Collective Violence and Democratization." Socius 4: 1-16.

Kawalerowicz, J. and M. Biggs. 2015. "Anarchy in the UK: Economic Deprivation, Social Disorganization, and Political Grievances in the London Riot of 2011." Social Forces 94(2):673-98.

Ketchley, N. 2017. Egypt in a Time of Revolution: Contentious Politics and the Arab Spring. Cambridge: Cambridge University Press.

Kuran, T. 1991. "Now Out of Never: The Element of Surprise in the East European Revolution of 1989." World Politics, 44(1): 7-48.

Kurtz, L.R. 2010. “Otpor and the Struggle for Democracy in Serbia (1998-2000).” International Centre on Nonviolent Conflict Summary Series. https://www.nonviolentconflict.org/wp-content/uploads/2016/02/Kurtz-Otpor-Serbia-5.pdf.

Lohmann, S. 1994. "The Dynamics of Informational Cascades: the Monday Demonstrations in Leipzig, East Germany 1989-91.”World Politics, 47(1): 42-101.

Marshall, M.G., T.R. Gurr and K. Jaggers. 2017. Polity IV Project Manual. http://www.systemicpeace.org/inscr/p4manualv2016.pdf.

Martin, B. 2007. Justice Ignited: The Dynamics of Backfire. Lanham: Rowman and Littlefield. 
Mason T.D., and J.A. Murtagh. 1985. "Who Riots? An Empirical Examination of the "New Urban Black" Versus the Social Marginality Hypotheses." Political Behavior, 7(4): 352373.

Mattaini, M.A. 2013. Strategic Nonviolent Power: The Science of Satyagraha. Athabasca: Athabasca University Press.

McAdam, D. 1982. Political Process and the Development of Black Insurgency. Chicago: Chicago University Press.

McAdam, D., J.D. Tarrow and M.N. Zald. 1996. Comparative Perspectives on Social Movements: Political Opportunities, Mobilizing Structures, and Cultural Framings. Cambridge: Cambridge University Press.

McAdam, D., J.D. Tarrow and C. Tilly. 2001. Dynamics of Contention. Cambridge: Cambridge University Press.

McCammon, H.J., E.M. Bergner and S.C. Arch. 2015. "Are You One of Those Women? Within-Movement Conflict, Radical Flank Effects, and Social Movement Political Outcomes." Mobilization 20(2): 157-178.

Moran, M., and D. Waddington. (2015). "Recent Riots in the UK and France: Causes and Commonalities." Contention: The Multidisciplinary Journal of the Social Protest 2(2): $57-73$.

Nepstad, S.E. 2015. Nonviolent Struggle: Theories, Strategies and Dynamics. Oxford: Oxford University Press.

Newburn, T. 2016. "The 2011 England Riots in European Context: A Framework for Understanding the 'Life-cycle' of Riots." European Journal of Criminology 13(5): 540555.

Obershall, A. 1973. Social Conflict and Social Movements. Englewood Cliffs: Pearson Education.

Olzak, S. 1987. "Causes of Ethnic Protest and Conflict in Urban America, 1877-1889." Social Science Research, 16: 185-210.

Opp, K-D. 2009. Theories of Political Protest and Social Movements: A Multidiscipline Introduction, Critique and Synthesis. London: Routledge.

Pearlman, W. 2011. Violence, Nonviolence, and the Palestinian National Movement. Cambridge: Cambridge University Press.

Pearlman, W. 2016. “Narratives of Fear in Syria.” Perspectives on Politics, 14(1): 21-37. 
Pinckney, J. 2016. Making or Breaking Nonviolent Discipline in Civil Resistance Movements. International Centre on Nonviolent Conflict Monograph Series. Washington DC: ICNC Press.

Popovic, S., and M. Miller. 2015. Blueprint for Revolution. How to use Rice Pudding, Lego Men, and Other Nonviolent Techniques to Galvanize Communities, Overthrow Dictators, or Simply Change the World. New York: Spiegel and Grau.

Piven, F.F., and R.A. Cloward. 1988. Poor Peoples Movements: Why They Succeed, How They Fail. New York: Random House.

Rivera Celestino, M. and K.S. Gleditsch. 2013. "Fresh Carnations or all Thorn, no Rose? Nonviolent Campaigns and Transitions in Autocracies." Journal of Peace Research, 50(3): 38-400.

Ritter, E.H. and C.R. Conrad. 2016. "Preventing and Responding to Dissent: The Observational Challenges of Explaining Strategic Repression." American Political Science Review, 110(1): 85-99.

Salehyan I., and C.S. Hendrix. 2012. "Social Conflict in Africa Database Version 3.0." Codebook and Coding Procedures. https://www.strausscenter.org/codebooks/SCAD\%203.0\%20Codebook.pdf.

Salehyan, I., C.S. Hendrix, J. Hamner, C. Case, C. Linebarger, E. Stull and J. Williams. 2012. "Social Conflict in Africa: A New Database." International Interactions, 38(4): 503-511.

Schock, Kurt. 2005. Unarmed Insurrection. People Power Movements in Nondemocracies. Minneapolis, MN: University of Minnesota Press.

Seferiades, S., and H. Johnston. 2012. Violent Protest, Contentious Politics, and the Neoliberal State. London: Routledge.

Sharp, G. 2005. Waging Nonviolent Struggle: 20th Century Practice and 21st Century Potential. Boston, MA: Porter Sargent.

START (National Consortium for the Study of Terrorism and Responses to Terrorism). 2018. Global Terrorism Dataset (https://www.start.umd.edu/gtd).

Sundberg, R., and E. Melander. 2013. "Introducing the UCDP Georeferenced Event Dataset", Journal of Peace Research, 50(4): 523-532.

Sutton, J., C.R. Butcher and I. Svensson. 2014. "Explaining Political Jiu-Jitsu: InstitutionBuilding and the Outcomes of Regime Violence against Unarmed Protests." Journal of Peace Research 51(5): 559-573.

Tilly, C. 1986. The Contentious French. Cambridge, MA: Harvard University Press. 
Tilly, C. 2003. The Politics of Collective Action. Cambridge: Cambridge University Press.

Toro, F. 2014. "Rash Repression in Venezuela." New York Times, $24^{\text {th }}$ February 2014. https://www.nytimes.com/2014/02/25/opinion/rash-repression-in-venezuela.html.

Wallace, J. 2013. "Cities, Redistribution, and Authoritarian Survival." Journal of Politics, 75(3): 632-645.

Wasow, O. 2017. "Do Protests Matter? Evidence from the 1960s Black Insurgency." Unpublished manuscript, Princeton University.

World Bank. 2016. World Development Indicators. http://data.worldbank.org/datacatalog/world-development-indicators. 


\section{Notes}

${ }^{1}$ To be clear on the key concepts, we here consider nonviolent mobilization in terms of organized and largescale campaigns with a clear political motive. Chenoweth and Stephan (2011: 14-15) define campaigns as "a series of observable, continual tactics in pursuit of a political objective", using various forms of the 198 nonviolent methods outlined by Sharp (2005). They distinguish between violent and nonviolent campaigns, based on the primary tactics used. This definition highlights active organization and the deliberate intent in choosing nonviolent direct action tactics. By protest, we mean specifically nonviolent protest using nonviolent tactics. We refer to Sharp (2005: 49-60) who notes 198 methods of specifically nonviolent resistance and consolidates this into three broad categories: persuasion (i.e. peaceful protests and demonstrations), non-cooperation (i.e. peaceful strikes and boycotts), and intervention (i.e. peaceful sit-ins and the overloading of state institutions). Our data contains individual, coordinated nonviolent anti-government events, which use a combination of these methods either leading up to, or taking place during campaigns. By riots, we mean "distinct, continuous and violent action directed toward members of a distinct 'other' group or government authorities" (see Salehyan and Hendrix 2012: 4). We see riots largely as a form of unorganized and uncoordinated violence which may or may not be present during and/or prior to otherwise nonviolent protests and nonviolent campaigns. Seferiades and Johnston (2012: 16) emphasize how riots can emerge from fringe groups in otherwise peaceful protests, or escalate from initial protests that become violent, often as response to police or state repression. This corresponds closely to what Tilly (2003: 15-16) refers to as "scattered attacks" and "broken negotiations". Riots are often referred to as a form of violent protest but are not always evidence in otherwise nonviolent incidents of resistance. In some cases rioting in more prevalent during nonviolent action than in others. We are primarily interested in the likelihood a nonviolent 
campaign with emerge or collapse given the degree of rioting that occurs during initial protests and ongoing nonviolent campaigns.

${ }^{2}$ Based on personal communications with Siniša Šikman.

${ }^{3}$ The NAVCO data (and the related MEC data after 2006) identify maximalist campaigns with more than 1000 participants, including campaigns that have nonviolent primary tactics. We explain these data sources in greater detail later.

${ }^{4}$ Many activities are "not violent". Our focus here is on what Sharp (2005: 543-548) calls nonviolent direct action, with claims on the government or regime change, using methods that are both a) nonviolent and b) direct action, outside conventional political channels or in contravention of what the state orders or permits, such as illegal strikes or protests. Many "not violent" activities, for example routine politics permitted within a system, or activities without a political claim, fall outside of our definition of nonviolent action.

${ }^{5}$ Nonviolent dissent is often met by government violence, but definitions of nonviolent tactics emphasize whether dissidents respond with violence and the extent to which this is organized or an explicit tactic. Similarly, definitions of civil war do not extend to events with one-sided state repression or violence against unorganized individuals, unless the non-state actor also confronts the state using organized armed violence. Pre-emptive state repression can deter mass-mobilization altogether (Davenport 2007; Ritter and Conrad 2016).

${ }^{6} \mathrm{We}$ focus on riots as a case of unorganized violence during dissent in our analysis, but also consider potential differential effects of more or less organized riots. We focus on riots, since we have reasonably good cross-national data, but we believe our arguments should extend to other forms of unorganized violence not recorded in existing data such as fighting with the police. We acknowledge that focusing on riots alone likely underestimates the full range of 
disorganized violence during dissent. As such, it is instructive that disorganized violence seems so common during dissent, even with our restricted focus on riots.

7 The NAVCO data are based on the Chenoweth and Stephan (2011: 14-5) definition a campaign (fn. 1, Chenoweth and Lewis 2013: 14). The operational definition requires that campaigns should entail maximalist goals and coordinated, continuous events with at least 1,000 observed participants, within one week of one another.

${ }^{8}$ We use various secondary sources to establish more precise start and end dates for campaigns. We assign January/December as start/end months if we cannot identify more precise dates. There are only four such cases, which when removed from the analysis provide identical results to those discussed in Table 2 .

9 A national or regional government must be coded as a target in the rioting or political parties/leaders and state-owned enterprises clearly aligned to the government. We use two SCAD dummy variables that code whether each event targeted the central and/or regional/local government (Salehyan and Hendrix 2012: 4). For fringe rioting, we use the SCAD event type category which includes violent riot events (p. 2) and for escalatory rioting, use SCAD's escalatory category, coding all protest events that specifically escalated into a riot (p. 3 ).

${ }^{10}$ The procedure also uses other details in SCAD about event locations. For example, if riots events are reported to take place in "mining areas", then they are assigned to major mining locations.

${ }^{11}$ The CNTS data define anti-government demonstrations as "any peaceful public gathering of at least 100 people for the primary purpose of displaying or voicing their opposition to government policies or authority, excluding demonstrations of a distinctly anti-foreign nature". 
General strikes are defined as "any strike of 1,000 or more industrial or service workers that involves more than one employer and that is aimed at national government policies or authority".

${ }^{12}$ We find no evidence for a significant interaction between rioting and protest in the prior year on the onset of nonviolent campaigns.

${ }^{13}$ Rioting that escalates from initial nonviolent protest may suggest an 'act of desperation', whereby rioting occurs in anticipation of the collapse of a nonviolent campaign. Yet, like all forms of rioting, this can occur as different stages of a nonviolent campaign, and further indicates the demobilizing effect escalatory rioting can have on ongoing nonviolent action. Moreover, the lack of clear differing effects of various types of rioting shows that riots, whether occurring alongside a campaign or escalating from nonviolent protests, have a general demobilizing impact on ongoing nonviolent resistance. 


\section{Appendix}

Table 3. Interactions (Riot X Repression) and the onset and duration of nonviolent campaigns

(9) (10) (11) (12) (13)

Onset Campaign Campaign Campaign Campaign

NVC Termination Termination Termination Termination

\begin{tabular}{|c|c|c|c|c|c|}
\hline Riot Events (Banks) t-1 & $\begin{array}{l}\mathbf{0 . 1 4 8}^{* *} \\
(0.056)\end{array}$ & & & & \\
\hline Protest Events (Banks) t-1 & $\begin{array}{l}-0.091^{*} \\
(0.045)\end{array}$ & & & & \\
\hline All Riots (SCAD) (t-1) & & $\begin{array}{l}0.154^{* * * *} \\
(0.025)\end{array}$ & & & \\
\hline Govt. Targeted Riots (t-1) & & & $\begin{array}{c}\mathbf{0 . 1 9 3}^{* * *} \\
(\mathbf{0 . 0 2 9})\end{array}$ & & \\
\hline Fringe Riots Only(t-1) & & & & $\begin{array}{c}\mathbf{0 . 2 1 2} \\
(\mathbf{0 . 0 3 3})\end{array}$ & \\
\hline Escalatory Riots Only (t-1) & & & & & $\begin{array}{c}\mathbf{0 . 2 8 3}^{* * * *} \\
(\mathbf{0 . 0 5 1})\end{array}$ \\
\hline Riot (Banks) X Repression & $\begin{array}{l}-0.011 \\
(0.071)\end{array}$ & & & & \\
\hline Riot (SCAD) X Repression & & $\begin{array}{l}-0.088 \\
(0.088)\end{array}$ & $\begin{array}{l}-0.165 \\
(0.102)\end{array}$ & $\begin{array}{c}-0.166^{+} \\
(0.100)\end{array}$ & $\begin{array}{l}-0.198 \\
(0.166)\end{array}$ \\
\hline National Population (log) & $\begin{array}{c}0.315^{* * *} \\
(0.061)\end{array}$ & $\begin{array}{l}-0.687^{*} \\
(0.335)\end{array}$ & $\begin{array}{l}-0.644^{+} \\
(0.336)\end{array}$ & $\begin{array}{l}-0.606^{+} \\
(0.311)\end{array}$ & $\begin{array}{l}-0.636^{*} \\
(0.322)\end{array}$ \\
\hline Urban Population (\%) & $\begin{array}{l}0.027^{* *} \\
(0.008)\end{array}$ & $\begin{array}{l}-0.023 \\
(0.029)\end{array}$ & $\begin{array}{l}-0.021 \\
(0.028)\end{array}$ & $\begin{array}{l}-0.020 \\
(0.027)\end{array}$ & $\begin{array}{l}-0.025 \\
(0.029)\end{array}$ \\
\hline GDP per Capita (log) & $\begin{array}{c}-0.552^{* * * *} \\
(0.152)\end{array}$ & $\begin{array}{c}0.508 \\
(0.547)\end{array}$ & $\begin{array}{c}0.433 \\
(0.516)\end{array}$ & $\begin{array}{c}0.451 \\
(0.536)\end{array}$ & $\begin{array}{c}0.472 \\
(0.474)\end{array}$ \\
\hline Polity2 & $\begin{array}{c}0.002 \\
(0.019)\end{array}$ & $\begin{array}{l}0.079^{+} \\
(0.047)\end{array}$ & $\begin{array}{l}0.084^{+} \\
(0.046)\end{array}$ & $\begin{array}{l}0.085^{+} \\
(0.047)\end{array}$ & $\begin{array}{r}0.069^{+} \\
(0.042)\end{array}$ \\
\hline Election Year & $\begin{array}{l}0.569^{* * *} \\
(0.177)\end{array}$ & $\begin{array}{c}0.354 \\
(0.354)\end{array}$ & $\begin{array}{c}0.302 \\
(0.344)\end{array}$ & $\begin{array}{c}0.294 \\
(0.349)\end{array}$ & $\begin{array}{c}0.366 \\
(0.347)\end{array}$ \\
\hline $\begin{array}{l}\text { V-Dem Physical Integrity } \\
\text { Index }\end{array}$ & $\begin{array}{l}-0.952^{+} \\
(0.493)\end{array}$ & & & & \\
\hline $\begin{array}{l}\text { Ratio of Nonlethal Repression } \\
\text { - SCAD (t-1) } \\
\text { Ratio of Lethal Repression } \\
\text { - SCAD }(\mathrm{t}-1)\end{array}$ & & $\begin{array}{l}0.462 \\
(0.700) \\
2.142^{* *} \\
(0.754)\end{array}$ & $\begin{array}{l}0.393 \\
(0.685) \\
2.222^{* *} \\
(0.688)\end{array}$ & $\begin{array}{l}0.479 \\
(0.641) \\
2.047^{* *} \\
(0.765)\end{array}$ & $\begin{array}{c}0.495 \\
(0.673) \\
2.489^{* * *} \\
(0.567)\end{array}$ \\
\hline Years since last NVC & $\begin{array}{l}-0.187^{*} \\
(0.073)\end{array}$ & & & & \\
\hline Constant & $\begin{array}{l}-5.104^{* * *} \\
(1.360) \\
\end{array}$ & & & & \\
\hline Observations & 5825 & 964 & 964 & 964 & 964 \\
\hline NVC Terminations & - & 36 & 36 & 36 & 36 \\
\hline
\end{tabular}

Standard errors in parentheses $+\mathrm{p}<0.10, * \mathrm{p}<0.05, * * \mathrm{p}<0.01, * * * \mathrm{p}<0.001$

Temporal splines in model 9 are not reported in order to condense the table. 